\title{
INFLUENCE OF ACETYL CHOLINE LEVEL ON PRODUCTIVE PERFORMANCE AND IMMUNE RESPONSES IN BROILER CHICKS
}

\author{
H.H.M., Hassanien ${ }^{1}$, Z. S. H. Ismaeil ${ }^{1}$, and H.M. Yakout ${ }^{2}$ \\ 1- Department of Animal and Poultry Production, Faculty of Agriculture, University of South \\ Valley, 2- Department of Poultry Production, Faculty of Agriculture, University of Alexandria, \\ 21545
}

\section{SUMMARY}

One hundred and twenty Hubbard broiler chicks at one day old of age were randomized and fed one of four dietary treatment diets differing in dietary acetyl choline (AC) levels (0, 5, 10 and $15 \mathrm{mg} / \mathrm{kg}$ feed), broilers within each dietary treatment were randomized into 3 replicates of 10 chickens each for the whole experimental period (6 weeks) from 0 to 6 weeks of age. Response criteria included production parameters, measures of blood physiological and immunological measurements.

Acetyl choline supplementation at $15 \mathrm{mg} / \mathrm{kg}$ diet significantly increased $B W$ at 3 weeks of age by $9.56 \%$, and numerically improved FCR by $8.0 \%$ as compared to those of control group. However, no significant effect of AC supplementation at 5 or $10 \mathrm{mg} / \mathrm{kg}$ feed on BWG, FI and FCR during all experimental periods. There were no statistical significant influences of the dietary choline level on serum glucose, cholesterol, and liver functions as judged by liver enzymes e.g. AST and ALT. On the other hand, choline dietary supplementation significantly increased serum total protein and was statistically similar to the un-supplemented controls (6.67, 6.79 and $6.70 \mathrm{~g} . / \mathrm{dl}$ ), respectively. Acetyl choline as at 10 or $15 \mathrm{mg} / \mathrm{kg}$ feed significantly increased serum globulin and were statistically similar, but different to the un-supplemented controls $(4.80$ and $4.85 \mathrm{vs} .3 .51 \mathrm{~g} . / \mathrm{dl}$ ), respectively. Similarly, albumin to globulin ratio was found to be statistically similar between the control and $5 \mathrm{mg} / \mathrm{kg}$ feed of acetyl choline, but differ significantly as compared to higher acetyl choline dietary levels of 10 and 15 $\mathrm{mg} / \mathrm{kg}$ feed, respectively.

In conclusion, growing broiler chicks responded positively to acetyl choline supplementation of 10 $\mathrm{mg} / \mathrm{kg}$ feed. Similar finding were noted with the same dietary acetyl choline inclusion with immunity parameters and blood physiological parameters within the study period from 0 to 6 weeks of age.

\section{Keywords: Acetyl Choline, Broiler, serum glucose, cholesterol}

\section{INTRODUCTION}

Choline plays many important metabolic roles in poultry, and to maximize the bird's growth or performance, the diet must contain choline. Since its discovery in hog bile by Strecker (1862), choline has been recognized as an essential dietary nutrient for most animal species. In the middle of the last century, Jukes (1940) first showed that choline was required for normal growth and prevention of the leg disorder perosis in turkeys. Chlorine is considered a member of the B-complex vitamin group and an essential nutrient in broilers, laying hens and other poultry diets for the formation of the phospholipid lecithin found in egg yolk and liver (Ewing, 1963). As characterized by (Combs, 2008; McDowell, 2000) there are few major functions for choline, including its role as a key metabolite for building and maintaining cell structure and plays an essential role in fat metabolism in the liver. Furthermore, choline is essential for the formation of acetyl choline and is a source of labile methyl groups for the formation of methionine from homocysteine. Finally, choline is required for neurotransmission and brain development (as acetyl choline) in both central and peripheral nervous systems. Requirements of choline are critical as it must be supplemented to young birds because they do not have fully functional S-methyl transferase enzymes at an early ages (Combs, 1998). As described by (Combs, 2008), there is an absolute requirement for dietary choline by broilers, especially at younger ages as the chick cannot synthesize sufficient amounts until up to 13 weeks of age.

NRC (1994) suggested that the choline requirement of broilers is 1,300 parts per million in the first 3 weeks of age and subsequently declines to only $1,000 \mathrm{ppm}$ from 3 to 6 weeks of age demonstrated the importance of choline for maximizing growth and improving feed conversion ratio when supplementing up to NRC requirements, a number of studies have also looked at the effect of supplementing choline above the levels suggested by NRC when feeding practical diets. These studies have found that the effect of choline supplementation is influenced by the level of sulfur amino acid 
(i.e., methionine and cysteine) content of the diet.

The objective of the proposed study was to determine the effect of supplemental acetyl choline on productive performance and immune responses of broilers. Our hypothesis was that supplementation of different dietary choline levels may generate additional methyl groups and add to the active methyl pool. This may lead to a positive performance and enhancing immunity indicators of broilers.

\section{MATERIALS AND METHODS}

\section{Experimental birds and management:}

This study was conducted at the Animal and Poultry Production Department, Faculty of Agriculture, South Valley University. One hundred and twenty Hubbard broiler chicks at one day old of age were randomized and fed one of four dietary treatment diets differing in dietary acetyl choline (AC) levels $(0,5,10$ and $15 \mathrm{mg} / \mathrm{kg}$ feed), broilers within each dietary treatment were randomized into 3 replicates of 10 chickens each. Feed and water were provided ad-libitum all over the experimental period (6 weeks) from 0 to 6 weeks of age.

\section{Experimental diets:}

The corn-soybean basal diet composition is presented in (Table 1). Treatments consisted of the basal diet which was a commercial ration containing approximately $0.15 \mathrm{mg}$ choline/ $\mathrm{kg}$ feed, to which had been added the following amounts of synthetic F (0, 5, 10 and $15 \mathrm{mg} / \mathrm{kg}$ feed). Dietary AC was added to the basal diet in a synthetic commercial form ${ }^{1}$, and dietary treatments were formulated to be iso-caloric (3250 kcal ME/ kg) and iso-nitrogenous (20\% $\mathrm{CP})$. Experimental diets were formulated to meet nutrients requirements according to the recommended levels of (NRC, 1994).

\section{Measurements:}

Daily feed consumption (FI) per bird, body weights (BW) and body weight gains (BWG) were recorded every 3 weeks, of which data were used to calculate feed conversion ratio (FCR) during the specified period.

\section{Blood Serum Measurements:}

Approximately $5 \mathrm{ml}$ of blood was collected from 5 chicken's wing vein on the $6^{\text {th }}$, week of the experimental period. Blood samples were centrifuged and the serum was collected and serum samples were stored at $-20^{\circ} \mathrm{C}$ for further analysis of plasma total proteins and lipids

\footnotetext{
${ }^{1}$ Egypt for Feed Additives Company (EFAC)
}

(Fisher and Leveille, 1957) by using commercial kits produced by Diamond Diagnostic3. Serum total immunoglobulin titre (STIT) was also determined according to Van der Zipp et al. (1983). Plasma total lipids were determined according to the method of Zollner and Kirsch (1962). Determination of plasma cholesterol was carried out according to the method of Ratlliff and Hall (1973). Plasma triglyceride was determined according to the method of Fossati (1983).

\section{Statistical analysis:}

All data was analyzed using the GLM procedures of SAS for a Complete Randomized Design (CRD). Dietary treatments (4 F inclusion levels) were considered fixed effects. Significant treatment differences were established using the LSMEANS statement in SAS (SAS, 2003). The following model was used to determine differences:

$\mathbf{Y i j}=\boldsymbol{\mu}+\mathbf{a i}+\mathbf{e i}$; where $\mathbf{Y i j}$ variable measured; $\boldsymbol{\mu}$ overall mean; $\mathbf{a i}=$ effect of the ith level and $\mathbf{e i j}=$ error component. Significance of difference was based on the probability of a type I error set at $(\mathrm{P} \leq 0.05)$. All differences among means were tested utilizing Duncan's multiple range test (Duncan, 1955).

\section{RESULTS AND DISCUSSION}

Acetyl choline supplementation at 15 $\mathrm{mg} / \mathrm{kg}$ diet significantly $(\mathrm{P} \leq 0.05)$ increased BW at 3 weeks of age by $9.56 \%$ (Table 2), and numerically improved FCR by $8.0 \%$ during the same period of age compared to those fed unsupplemented control diet (Table 3), respectively. There was no significant effect of acetyl choline supplementation at 5 or 10 $\mathrm{mg} / \mathrm{kg}$ feed on BWG, FI and FCR during all experimental period, nor was there a significant impact of either 5 or $10 \mathrm{mg}$ acetyl choline on FCR during 0-3, 3-6 as well as 0-6 weeks of age. Although, acetyl choline at 10 $\mathrm{mg} / \mathrm{kg}$ feed tended to slightly $(\mathrm{P} \geq 0.05)$ improve FCR during 3-6 as well as 0-6 week of age by 9.09 and $4.89 \%$, respectively as compared to the control diet.

Growth of growing broilers during 0-3 weeks of age was significantly improved due to acetyl choline dietary supplementation, while during the periods of 3-6 as well as 0-6 weeks of age it was numerically improved. This may be depended on choline or methionine contents of the experimental diets utilized within the trial; fat level and ability of chicks to synthesis choline via hepatic synthesis (Venugopal, 1985; Ghazalah, 1998 and Workel et al., 1999). Present results showed that the response to acetyl choline 
dietary supplementation was diminished at 5 $\mathrm{mg} / \mathrm{kg}$ feed of added acetyl choline (Table $2 \&$ 3 ). It was also noted that growth stimulating and feed utilization improving effect of choline is greater than that of the control and other acetyl choline levels up to $10 \mathrm{mg} / \mathrm{kg}$ feed.

Present results are in agreement with those of Menten et al. (1997) who found greater response to supplemented choline when basal diet containing low level of choline. Along the same line, Emmert et al. (1996) reported that choline supplementation to methionine deficient diet significantly increased growth and improved FCR. It was shown that choline addition to methionine deficient diets improved growth of chicks especially during early phase of growth (Pesti et al., 1980 and Harms and Miles, 1984). In the present study, it should be noted however, that methionine level of the basal diet was adequate to meet chick's requirements of the $1^{\text {st }}$ limiting amino acid and methyl group donor. However, methyl group donors have been shown specificity in body functions, and blood uptake of choline and methionine were slower in comparison to betaine (Kettunen et al., 2001a and b).

Additionally, Rostagno and Pack (1995), Schutte et al. (1997) and McDevitt et al. (2000) reported that choline can reduce the requirements of methionine by furnishing methyl groups, but cannot reduce the need for dietary methionine when the diet contain inadequate level of choline. It was also shown that the growth response to choline or supplementation declined with increasing age of chicks, indicating that methyl donor requirements are higher during early growth phase than latter growth period (Table $2 \& 3$ ). Similar results were reported with ducks by Wang et al. (2004). Also, NRC (1994) cited data indicated that choline requirements for leghorns, broilers and turkeys and this declined with increasing age of chicks and depends on strains and type as well as growth potential of chickens.

On the other hand, the lack of responses to increasing dietary acetyl choline levels to 15 $\mathrm{mg} / \mathrm{kg}$ feed, indicating that a saturation of growth and FCR at $15 \mathrm{mg}$ of choline $/ \mathrm{kg}$ diet showing that it is adequate for growing chicks. So, based on previous findings and published reports findings it is noted that the involvement of choline in lipid metabolism would offer an interesting opportunity to poultry industry to satisfy consumer desire and improve feed conversion ratio.

There were no statistical significant influences of the dietary choline level on serum glucose, cholesterol, and liver functions as judged by liver enzymes e.g. AST and ALT (Table 4). On the other hand, choline dietary supplementation significantly $\quad(\mathrm{P} \leq 0.05)$ affected serum total protein, albumin and globulin. It was found that acetyl choline as an independent variable at 10 or $15 \mathrm{mg} / \mathrm{kg}$ feed significantly $(\mathrm{P} \leq 0.05)$ increased serum total protein and was statistically similar to the unsupplemented controls (6.67, 6.79 and 6.70 g./ dl), respectively (Table 4). However, acetyl choline at 10 or $15 \mathrm{mg} / \mathrm{kg}$ feed were statistically similar and significantly higher that the un-supplemented controls during the recovery period (7 wks of age). Furthermore, during the same period dietary acetyl choline supplementation followed similar trend of total protein in globulin (g./ dl). It was found that acetyl choline as at 10 or $15 \mathrm{mg} / \mathrm{kg}$ feed significantly $\quad(\mathrm{P} \leq 0.05) \quad$ increased serum globulin and were statistically similar, but different to the un-supplemented controls (4.80 and 4.85 vs. 3.51 g./ dl), respectively (Table 4). In the same line, albumin to globulin ratio was found to be statistically similar between the control and $5 \mathrm{mg} / \mathrm{kg}$ feed of acetyl choline, but differ significantly $(\mathrm{P} \leq 0.05)$ when compared to higher acetyl choline dietary levels of 10 and $15 \mathrm{mg} / \mathrm{kg}$ feed, respectively.

The improvement in serum total protein and globulin due to acetyl choline dietary supplementation indicated further evidence about the role of methyl donor groups in protein metabolism (Table 4). The positive effect of choline in serum protein was confirmed by the improvement in antibody responses to SRBC's (Table 6), showing the positive effect of choline on immune functions. Improvements in the primary antibody titer of chicks due to choline are in general agreement with those of Remus et al. (2004) who concluded an increasing in broilers immunity.

In this concern, it should be kept in mind that there were effects of choline supplementation on serum protein $(P \leq 0.05)$ and globulin $(P \leq 0.05)$ and had insignificant effect on albumin serum as compared to the control group. Similar to the present findings, Swain and Johri (2000) found that choline supplementation at 2300 and $3300 \mathrm{mg} / \mathrm{kg}$ feed improved cellular and humoral immune responses. However, early study by Tsiagbe et al. (1987) indicated that choline supplementation of 0.125 or $0.25 \%$ to $0.13 \%$ choline containing diet did not affect total antibodies, IgG and IgM and mitogen PHA-P.

In conclusion, growing broiler chicks gained $34.15 \mathrm{~g} / \mathrm{d}$ during 0 to 6 weeks of age required acetyl choline level of $10 \mathrm{mg} / \mathrm{kg}$ feed. Similar finding were noted with the same dietary choline inclusion with immunity parameters and blood physiological parameters.

\section{REFERENCES}

Combs, G.F.Jr., 1998. The VitaminsFundamental aspects in nutrition and 
health. 2nd Edition. Academic Press, San Diego, CA.

Emmert, J.I., T.A. Garrow and D.H. Baker, 1996. Hepatic betaine-homocysteine methyltrans ferase activity in the chicken is influenced by dietary intake of sulfus amino acids, choline and betaine. J. Nutr., 126:2050-2058.

Ewing, 1963. Ewing, R. W., 1963. Poultry Nutrition, $5^{\text {th }}$ Ed. The Ray Ewing Co, Pasadena, CA.

Ghazalah, A.A., 1998. The choline requirements of broiler chicks fed fat supplemented diets. Egypt. Poult. Sci., 18: 271-289.

Harms, R. H. and R. D. Miles, 1984. Effect of supplemental methionine and potassium sulfate on the choline requirement of the turkey poults. Poult. Sci., 63: 1464-1466.

Jukes, 1940. Choline's key role in poultry diet revisited. Feedstuffs, July 5, 2010.

Kettunen, H., K. Tiihonen, S. Peuranen, M. T. Saarine and J.C. Remus, 2001a. Dietary betaine accumulates in the liver and intestinal tissue and stabilizes the intestinal epithelial structure in healthy and coccidiainfected broiler chicks. Comp. Bioch. and Physiol. Part A, 130: 759-769.

Kettunen, H., S. Peuranen, K. Tiihonen and M. T. Saarinen, 2001b. Intestinal uptake of betaine in vitro and the distribution of methyl groups from betaine, choline and methionine in the body of broiler chicks. Comp. Bioch. and Physiol. Part A, 128: 269-278.

McDowell, 2000)

McDevitt, R. M., S. Mack and I. R. Wallis, 2000. Can betaine partially replace or enhance the effect of methionine by improving broiler growth and carcass characteristics? Br. Poult. Sci., 41: 473480.

Menten, J. F. M., G. M. Pesti and R. I. Bakalli, 1997. A new method for determining the availability of choline in soybean meal. Poult. Sci., 76: 1292.

National Research Council, 1994. Nutrient Requirements of Poultry. $9^{\text {th }}$ revised
Edition, National Academy Press. Washington DC., USA.

Pesti, G.M., N. J. Benevenga, A. E. Harper and M. L. Sunde, 1981. The effect of high dietary protein and nitrogen levels on the performance, methyl group requirement and methionine induced growth depression in chicks. Poult. Sci., 60: 425-432.

Schutte, J.B., J. Dejong, W. Smink and M. Pack, 1997. Replacement value of betaine for DL- methionine in male broiler chicks. Poult. Sci., 76: 321-325.

Strecker, 1862. Uher einge neus bestandtheild der schweingalle. Annalen der chamine und Pharmocie., 360.

Swain, B.K. and T.S. Johri, 2000. Effect of supplemental methionine, betaine and their combinations on the performance and immune response of broilers. Br. Poult. Sci., 41: 83-88.

Tsiagbe, V.K., M.E. Cook, A. E. Haper and M. L. Sunde, 1987. Enhanced immune responses in broiler chicks fed methioninesupplemented diets. Poult. Sci., 66: 11471154.

Remus, J.C., E.E.M. Pierson and M. Hruby, 2004. The evaluation of betaine and enzymes in coccidian challenged broilers. XXII Poultry Congress, Istanbul, Turkey 813 June, 2004.

Rostagno, H.S. and M. Pack, 1995. Dose betaine have a sparing effect for supplemental DL-methionine in broiler diets. J. Appl. Poult. Res., 5: 150-154.

Wang, Y.Z., Z. R. Xu and G. Feng, 2004. The effect of betaine and DL-methionine on growth performance and carcass characteristics in meat ducks. Anim. Feed Sci. Tech., 116: 151-159.

Workel, H.A., T.B. Keller, A. Reeve and A. Lauwaerts, 1999. Choline- The rediscovered vitamin. Poult. Int., April, 1999: 44-47.

Venugopal, P.B., 1985. Choline, in "Methods of Vitamin A" $4^{\text {th }}$ Ed. John Wiley \& Sons. A Wiley Interscience Publication New York, Published for the Association of Vitamins Chemists. 
Table 1. Composition and calculated analysis of experimental diets

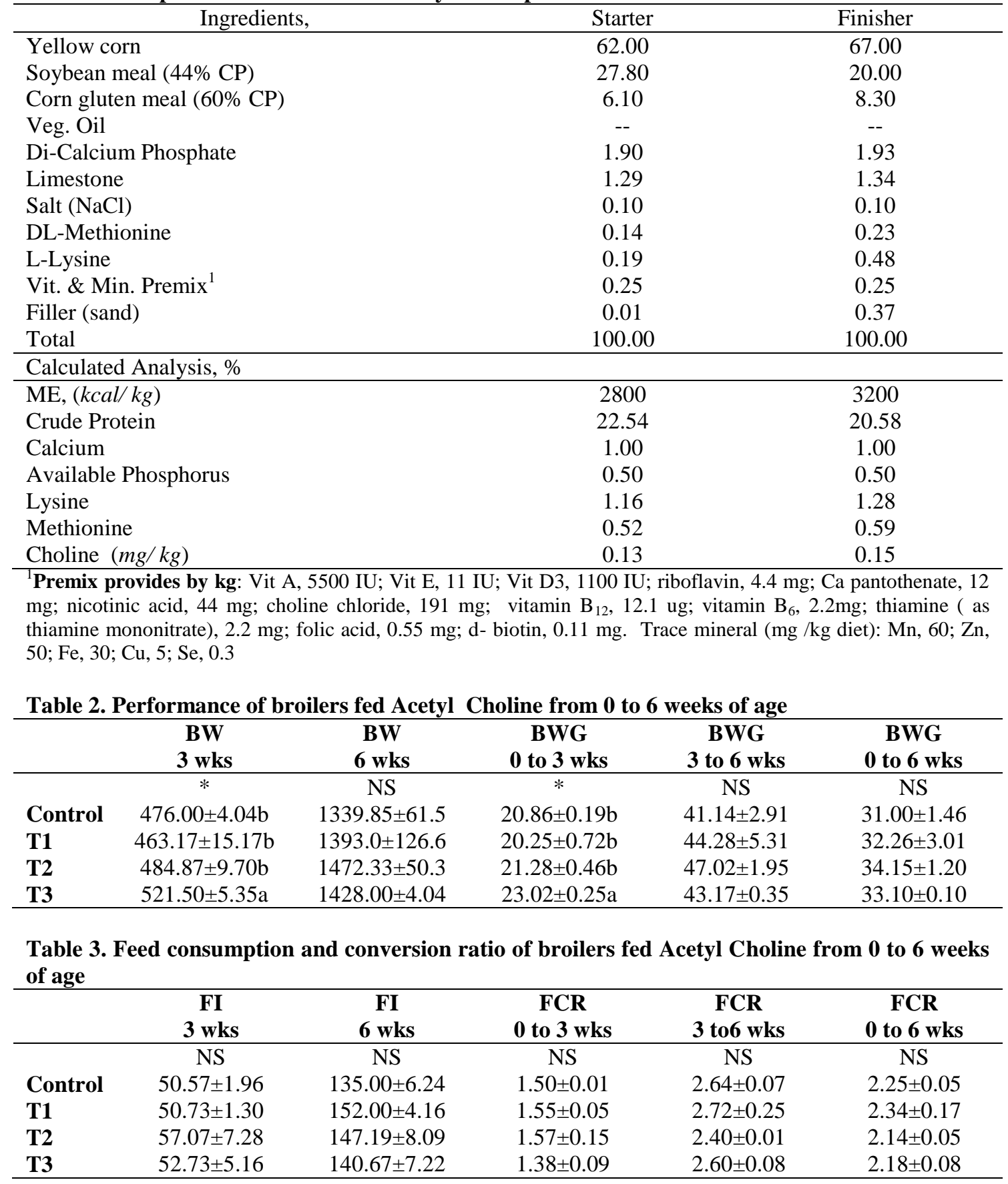


Table 4. Effect of feeding broilers Acetyl Choline from 0 to 6 weeks of age on blood physiological parameters

\begin{tabular}{|c|c|c|c|c|c|c|c|c|c|c|}
\hline \multirow{2}{*}{ Parameter } & \multicolumn{2}{|c|}{ Control } & \multicolumn{2}{|c|}{ T1 } & \multicolumn{2}{|c|}{$\mathbf{T 2}$} & \multicolumn{2}{|c|}{ T3 } & \multicolumn{2}{|c|}{ Probabilities } \\
\hline & 6 wks & 7 wks & 6 wks & 7 wks & 6 wks & 7 wks & 6 wks & 7 wks & $6 \mathrm{wks}$ & $7 \mathrm{wks}$ \\
\hline $\begin{array}{l}\text { Glucose } \\
(\mathrm{mg} / \mathrm{dl})\end{array}$ & $\begin{array}{l}104.7 \\
\pm 3.49\end{array}$ & $\begin{array}{l}107.4 \\
\pm 2.55\end{array}$ & $\begin{array}{l}111.6 \\
\pm 2.97\end{array}$ & $\begin{array}{l}113.4 \\
\pm 2.50\end{array}$ & $\begin{array}{l}112.0 \\
\pm 4.54\end{array}$ & $\begin{array}{l}114.5 \\
\pm 4.32\end{array}$ & $\begin{array}{l}115.9 \\
\pm 4.48\end{array}$ & $\begin{array}{l}119.4 \\
\pm 5.93\end{array}$ & NS & NS \\
\hline $\begin{array}{l}\text { Cholesterol } \\
(\mathrm{mg} / \mathrm{dl})\end{array}$ & $\begin{array}{l}154.9 \\
\pm 1.96\end{array}$ & $\begin{array}{l}175.5 \\
\pm 4.27\end{array}$ & $\begin{array}{l}152.9 \\
\pm 3.40\end{array}$ & $\begin{array}{l}182.4 \\
\pm 4.49\end{array}$ & $\begin{array}{l}150.0 \\
\pm 2.94\end{array}$ & $\begin{array}{l}175.5 \\
\pm 0.98\end{array}$ & $\begin{array}{l}150.9 \\
\pm 3.53\end{array}$ & $\begin{array}{l}182.4 \\
\pm 4.49\end{array}$ & NS & NS \\
\hline $\begin{array}{l}\text { GOT } \\
(\mathbf{U} / \mathrm{L})\end{array}$ & $\begin{array}{c}8.00 \\
\pm 1.00\end{array}$ & $\begin{array}{l}11.00 \\
\pm 4.00\end{array}$ & $\begin{array}{l}11.00 \\
\pm 2.65\end{array}$ & $\begin{array}{c}9.00 \\
\pm 1.00\end{array}$ & $\begin{array}{c}7.00 \\
\pm 0.00\end{array}$ & $\begin{array}{l}12.00 \\
\pm 3.61\end{array}$ & $\begin{array}{c}7.00 \\
\pm 0.00\end{array}$ & $\begin{array}{c}7.00 \\
\pm 0.00\end{array}$ & NS & NS \\
\hline $\begin{array}{l}\text { GPT } \\
(\mathbf{U} / \mathbf{L})\end{array}$ & $\begin{array}{l}72.00 \\
\pm 0.00\end{array}$ & $\begin{array}{c}82.67 \\
\pm 3.18^{\mathrm{a}}\end{array}$ & $\begin{array}{l}72.00 \\
\pm 2.89\end{array}$ & $\begin{array}{c}73.67 \\
\pm 1.67^{b}\end{array}$ & $\begin{array}{l}68.67 \\
\pm 1.67\end{array}$ & $\begin{array}{c}73.67 \\
\pm 1.67^{b}\end{array}$ & $\begin{array}{l}72.00 \\
\pm 0.00\end{array}$ & $\begin{array}{c}75.33 \\
\pm 1.67^{b}\end{array}$ & NS & $*$ \\
\hline $\begin{array}{l}\text { Total } \\
\text { protein } \\
\text { (g./dl) }\end{array}$ & $\begin{array}{c}6.80 \\
\pm 0.06^{\mathrm{a}}\end{array}$ & $\begin{array}{c}5.31 \\
\pm 0.12 b\end{array}$ & $\begin{array}{c}6.39 \\
\pm 0.10^{\mathrm{b}}\end{array}$ & $\begin{array}{c}5.33 \\
\pm 0.16^{\mathrm{b}}\end{array}$ & $\begin{array}{c}6.67 \\
\pm 0.04^{\mathrm{a}}\end{array}$ & $\begin{array}{c}6.38 \\
\pm 0.11^{\mathrm{a}}\end{array}$ & $\begin{array}{c}6.79 \\
\pm 0.03 \mathrm{a}\end{array}$ & $\begin{array}{c}6.45 \\
\pm 0.04^{\mathrm{a}}\end{array}$ & $* *$ & $* *$ \\
\hline $\begin{array}{l}\text { Albumen } \\
\text { (g./dl) }\end{array}$ & $\begin{array}{c}2.14 \\
\pm 0.04^{\mathrm{a}}\end{array}$ & $\begin{array}{c}1.80 \\
\pm 0.05\end{array}$ & $\begin{array}{c}1.83 \\
\pm 0.07^{b}\end{array}$ & $\begin{array}{c}1.63 \\
\pm 0.04\end{array}$ & $\begin{array}{c}1.74 \\
\pm 0.06^{\mathrm{b}}\end{array}$ & $\begin{array}{c}1.58 \\
\pm 0.11\end{array}$ & $\begin{array}{c}1.66 \\
\pm 0.09 \mathrm{~b}\end{array}$ & $\begin{array}{c}1.61 \\
\pm 0.06\end{array}$ & $* *$ & NS \\
\hline $\begin{array}{l}\text { Globulin } \\
\text { (g. /dl) }\end{array}$ & $\begin{array}{c}4.66 \\
\pm 0.03^{b c}\end{array}$ & $\begin{array}{c}3.51 \\
\pm 0.13^{b}\end{array}$ & $\begin{array}{c}4.56 \\
\pm 0.14^{\mathrm{c}}\end{array}$ & $\begin{array}{c}3.69 \\
\pm 0.19^{\mathrm{b}}\end{array}$ & $\begin{array}{c}4.92 \\
\pm 0.08^{\mathrm{ab}}\end{array}$ & $\begin{array}{c}4.80 \\
\pm 0.07^{\mathrm{a}}\end{array}$ & $\begin{array}{c}5.13 \\
\pm 0.06 \mathrm{a}\end{array}$ & $\begin{array}{c}4.85 \\
\pm 0.03^{\mathrm{a}}\end{array}$ & $* *$ & $* *$ \\
\hline $\begin{array}{l}\text { Alb./ Glob } \\
\text { ratio }\end{array}$ & $\begin{array}{c}0.46 \\
\pm 0.01^{\mathrm{a}} \\
\end{array}$ & $\begin{array}{r}0.52 \\
\pm 0.03^{\mathrm{a}} \\
\end{array}$ & $\begin{array}{c}0.40 \\
\pm 0.03^{\mathrm{ab}} \\
\end{array}$ & $\begin{array}{c}0.45 \\
\pm 0.03^{\mathrm{a}} \\
\end{array}$ & $\begin{array}{c}0.35 \\
\pm 0.02^{\text {bc }} \\
\end{array}$ & $\begin{array}{c}0.33 \\
\pm 0.02^{\mathrm{b}} \\
\end{array}$ & $\begin{array}{r}0.32 \\
\pm 0.02 \mathrm{c} \\
\end{array}$ & $\begin{array}{c}0.33 \\
\pm 0.01^{\mathrm{b}} \\
\end{array}$ & $* *$ & $* *$ \\
\hline
\end{tabular}

Table 5. Effects of feeding broilers Acetyl Choline from 0 to 6 weeks of age on white blood cells differentiation

\begin{tabular}{|c|c|c|c|c|c|c|c|c|c|c|}
\hline \multirow[b]{2}{*}{ Parameter } & \multicolumn{2}{|c|}{ Control } & \multicolumn{2}{|c|}{ T1 } & \multicolumn{2}{|c|}{$\mathbf{T 2}$} & \multicolumn{2}{|c|}{ T3 } & \multicolumn{2}{|c|}{ Probabilities } \\
\hline & $6 \mathrm{wks}$ & $\begin{array}{c}7 \\
\text { wks }\end{array}$ & 6 wks & 7 wks & $6 \mathrm{wks}$ & 7 wks & $6 \mathrm{wks}$ & 7 wks & 6 wks & $7 \mathrm{wks}$ \\
\hline $\begin{array}{l}\text { Monocyte } \\
\left(\mathrm{N} / \mathrm{mm}^{3}\right)\end{array}$ & $\begin{array}{c}2.00 \\
\pm 0.58\end{array}$ & $\begin{array}{c}2.33 \\
\pm 0.33\end{array}$ & $\begin{array}{c}2.00 \\
\pm 0.00\end{array}$ & $\begin{array}{c}2.00 \\
\pm 0.00\end{array}$ & $\begin{array}{c}1.67 \\
\pm 0.33\end{array}$ & $\begin{array}{c}2.33 \\
\pm 0.33\end{array}$ & $\begin{array}{c}1.67 \\
\pm 0.33\end{array}$ & $\begin{array}{c}2.33 \\
\pm 0.33\end{array}$ & NS & NS \\
\hline $\begin{array}{l}\text { Heterophill } \\
\left(\mathrm{N} / \mathrm{mm}^{3}\right)\end{array}$ & $\begin{array}{l}35.00 \\
\pm 1.15\end{array}$ & $\begin{array}{l}33.33 \\
\pm 1.20\end{array}$ & $\begin{array}{l}35.67 \\
\pm 0.88\end{array}$ & $\begin{array}{l}34.33 \\
\pm 0.33\end{array}$ & $\begin{array}{l}34.33 \\
\pm 0.33\end{array}$ & $\begin{array}{l}33.33 \\
\pm 1.45\end{array}$ & $\begin{array}{l}34.67 \\
\pm 0.33\end{array}$ & $\begin{array}{l}34.00 \\
\pm 1.53\end{array}$ & NS & NS \\
\hline $\begin{array}{l}\text { Lymphocyte } \\
\left(\mathrm{N} / \mathrm{mm}^{3}\right)\end{array}$ & $\begin{array}{l}57.33 \\
\pm 0.88\end{array}$ & $\begin{array}{l}57.33 \\
\pm 0.88\end{array}$ & $\begin{array}{l}54.00 \\
\pm 2.89\end{array}$ & $\begin{array}{l}54.00 \\
\pm 2.89\end{array}$ & $\begin{array}{l}54.33 \\
\pm 1.86\end{array}$ & $\begin{array}{l}54.33 \\
\pm 1.86\end{array}$ & $\begin{array}{l}57.00 \\
\pm 1.15\end{array}$ & $\begin{array}{l}57.00 \\
\pm 1.15\end{array}$ & NS & NS \\
\hline
\end{tabular}

Table 6. Effect of feeding broilers Acetyl Choline from 0 to 6 weeks of age on immunity and Thyroid hormones

\begin{tabular}{|c|c|c|c|c|c|c|c|c|c|c|}
\hline \multirow{2}{*}{ Parameter } & \multicolumn{2}{|c|}{ Control } & \multicolumn{2}{|c|}{ T1 } & \multicolumn{2}{|c|}{$\mathbf{T 2}$} & \multicolumn{2}{|c|}{ T3 } & \multicolumn{2}{|c|}{ Probabilities } \\
\hline & 6 wks & 7 wks & 6 wks & 7 wks & 6 wks & 7 wks & 6 wks & 7 wks & 6 wks & $7 \mathrm{wks}$ \\
\hline Immunoglobulin & $\begin{array}{c}5.91 \\
\pm 0.08^{c}\end{array}$ & --- & $\begin{array}{c}6.04 \\
\pm 0.07^{c}\end{array}$ & --- & $\begin{array}{c}6.31 \\
\pm 0.07^{b}\end{array}$ & --- & $\begin{array}{c}6.73 \\
\pm 0.06^{\mathrm{a}}\end{array}$ & --- & $*$ & --- \\
\hline T3 & $\begin{array}{c}3.41 \\
\pm 0.05^{\mathrm{a}}\end{array}$ & $\begin{array}{c}3.54 \\
\pm 0.15\end{array}$ & $\begin{array}{c}2.46 \\
\pm 0.02^{b}\end{array}$ & $\begin{array}{c}2.64 \\
\pm 0.31\end{array}$ & $\begin{array}{c}2.70 \\
\pm 0.20^{b}\end{array}$ & $\begin{array}{c}2.63 \pm \\
0.07\end{array}$ & $\begin{array}{c}2.29 \\
\pm 0.29^{b}\end{array}$ & $\begin{array}{c}2.55 \\
\pm 0.10\end{array}$ & $*$ & NS \\
\hline T4 & $\begin{array}{c}8.33 \\
\pm 0.88^{\mathrm{a}}\end{array}$ & $\begin{array}{l}13.33 \\
\pm 3.67 \\
\end{array}$ & $\begin{array}{c}8.00 \\
\pm 1.15^{\mathrm{b}}\end{array}$ & $\begin{array}{l}11.00 \\
\pm 2.08\end{array}$ & $\begin{array}{c}6.33 \\
\pm 0.88^{\mathrm{b}} \\
\end{array}$ & $\begin{array}{c}6.67 \pm \\
0.67 \\
\end{array}$ & $\begin{array}{c}5.67 \\
\pm 0.33^{\mathrm{b}} \\
\end{array}$ & $\begin{array}{c}6.00 \\
\pm 0.58 \\
\end{array}$ & * & NS \\
\hline
\end{tabular}


تأثير مستوى الاسيتيل كولين على الاداء الانتاجى و الاستجابة المناعية فى كتاكيت انتاج اللحم

حسام حسين محمد حسانين'، زينهم شيخون حسن'، هيثم محمد ياقوت '

ا - قسم الإنتاج الحيوانى والدواجن، كلية الزراعة، جامعة جنوب الوادى، قنا، مصر، ؟ ـ قسم إنتاج الدواجن، كلية الزراعة، جامعة الاسكندرية، الاسكندرية، مصر الإنى

استخدم • r ا كتوت لحم من سلالة الهبرد على عمر يوم حيث تم توزيعه عشو ائيا ليتغذوا على واحدة من اربعة معاملات تجريبية

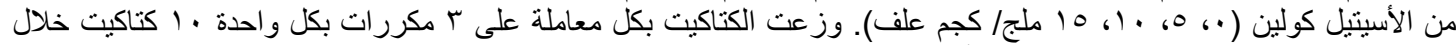

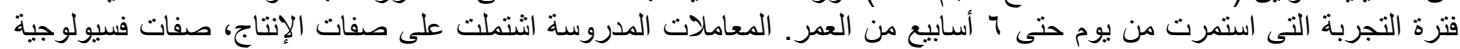

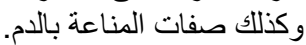

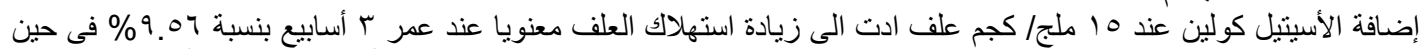

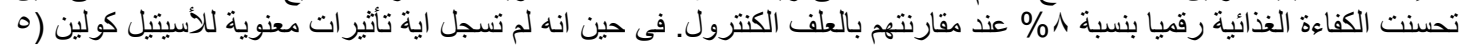

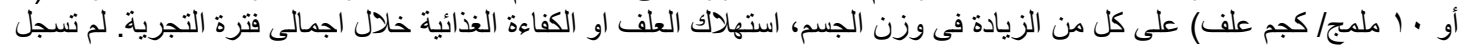

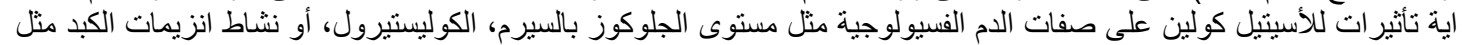

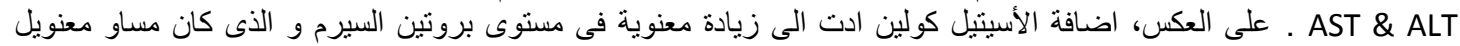

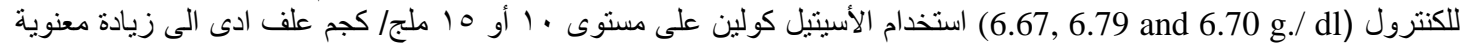

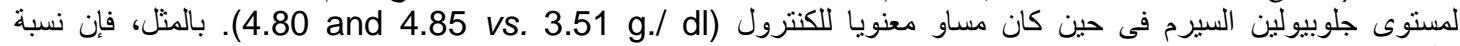

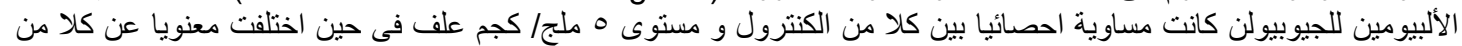

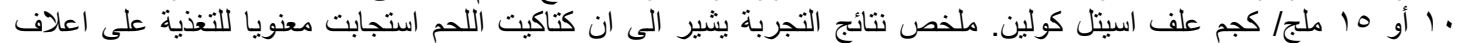

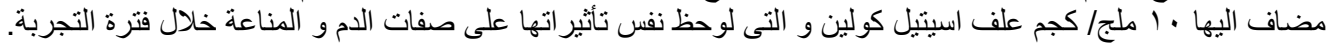

